Published in final edited form as:

Biochemistry. 2004 September 7; 43(35): 11175-11186.

\title{
Ca' ${ }^{2+}$ Binding to EF Hands 1 and 3 Is Essential for the Interaction of Apoptosis-Linked Gene-2 with Alix/AIP1 in Ocular Melanoma†
}

\author{
Lalita Subramanian $\ddagger$, Arthur S. Polans ${ }^{\star}, \ddagger, \perp$, Teresa M. Walker ${ }^{\perp}$, Paul R. van Ginkel $^{\perp}$, Saswati \\ Bhattacharya $^{\perp}$, and Julia M. Dellaria ${ }^{\perp}$ \\ Department of Biomolecular Chemistry University of Wisconsin, Madison, Wisconsin 53792 \\ Department of Ophthalmology and Visual Sciences, University of Wisconsin, Madison, Wisconsin \\ 53792
}

\author{
John W. Crabb§ \\ Cole Eye Institute and Lerner Research Institute, Cleveland Clinic Foundation, Cleveland, Ohio \\ 44195 \\ Jos Cox"l and Isabelle Durusselll \\ Department of Biochemistry, University of Geneva, Geneva 1211, Switzerland \\ Krzysztof Palczewski ${ }^{\nabla}$ \\ Departments of Ophthalmology, Pharmacology, and Chemistry, University of Washington, Seattle, \\ Washington 98195
}

\section{Abstract}

\begin{abstract}
Apoptosis-linked gene-2 ( $A L G$-2) encodes a $22 \mathrm{kDa} \mathrm{Ca}^{2+}$-binding protein of the penta EF-hand family that is required for programmed cell death in response to various apoptotic agents. Here, we demonstrate that $A L G-2$ mRNA and protein are down-regulated in human uveal melanoma cells compared to their progenitor cells, normal melanocytes. The down regulation of ALG-2 may provide melanoma cells with a selective advantage. ALG-2 and its putative target molecule, Alix/AIP1, are localized primarily in the cytoplasm of melanocytes and melanoma cells independent of the intracellular $\mathrm{Ca}^{2+}$ concentration or the activation of apoptosis. Cross-linking and analytical centrifugation studies support a single-species dimer conformation of ALG-2, also independent of $\mathrm{Ca}^{2+}$ concentration. However, binding of $\mathrm{Ca}^{2+}$ to both EF-1 and EF-3 is necessary for ALG-2 interaction with Alix/AIP1 as demonstrated using surface plasmon resonance spectroscopy. Mutations in EF-5 result in reduced target interaction without alteration in $\mathrm{Ca}^{2+}$ affinity. The addition of N-terminal ALG-2 peptides, residues 1-22 or residues 7-17, does not alter the interaction of ALG-2 or an N-terminal deletion mutant of ALG-2 with Alix/AIP1, as might be expected from a model derived from the crystal structure of ALG-2. Fluorescence studies of ALG-2 demonstrate that an increase in surface hydrophobicity is primarily due to $\mathrm{Ca}^{2+}$ binding to $\mathrm{EF}-3$, while $\mathrm{Ca}^{2+}$ binding to EF-1 has little effect on surface exposure of hydrophobic residues. Together, these data indicate that gross surface hydrophobicity changes are insufficient for target recognition.
\end{abstract}

\footnotetext{
${ }^{\dagger}$ This work was supported by NIH Grants EY12768 and EY13705 (A.S.P.), EY08061 (K.P.), and EY06603 and EY14239 (J.W.C.) and the Swiss National Science Foundation 31-65071.01 (J.C.), as well as grants from the Retina Research Foundation, Research to Prevent Blindness Inc. (RPB), the University of Wisconsin Comprehensive Cancer Center, and the E. K. Bishop Foundation. L.S. is a recipient of the Cremer Scholarship. A.S.P. is a Jules and Doris Stein RPB Professor.

*To whom correspondence should be addressed. Tel: 608-265-4423. Fax: 608-265-6021. E-mail: aspolans@ facstaff.wisc.edu.

\$Department of Biomolecular Chemistry, University of Wisconsin.

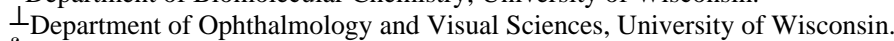

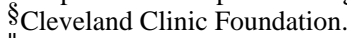

"University of Geneva.

$\nabla_{\text {University of Washington. }}$
} 
Apoptosis-linked gene-2 (ALG-2) was first identified in a death-trap assay using a mouse T cell hybridoma model (1). These cells when transfected with an antisense ALG-2 expression vector were resistant to $\mathrm{T}$ cell receptor-mediated cell death and were partially protected from other agents that normally initiate programmed cell death such as Fas, staurosporine, actinomycin $\mathrm{D}$, and $\mathrm{C}_{2}$-ceramide (1). More recent work suggests that ALG-2 might be involved in the apaf1-independent intrinsic apoptotic pathway activated as a result of endoplasmic reticulum (ER) stress (2).

ALG-2 contains five putative EF-hand sequences and is a member of the family of PEF ${ }^{1}$ (pentaEF-hand) proteins that includes the calpain small subunit, sorcin, and grancalcin (3). In ALG-2, EF-1 and EF-3 are considered the high-affinity $\mathrm{Ca}^{2+}$-binding sites, while one low-affinity site was also detected, which may correspond to EF-5 (4). Studies using recombinant mouse ALG-2 indicated that the solubility of the protein in the presence of $\mathrm{Ca}^{2+}$ is enhanced when the Nterminal hydrophobic non-PEF region was deleted, suggesting that this region might be exposed as a result of $\mathrm{Ca}^{2+}$ binding, leading to protein aggregation (3-5). Cross-linking studies using the recombinant protein and deletion mutants (3) also showed that at elevated protein concentrations, ALG-2 formed a weak homodimer even in the absence of $\mathrm{Ca}^{2+}$. The crystal structure of a truncated form of ALG-2 identified the C-terminal domain, consisting of the fifth EF-hand, as the region involved in the formation of the dimer complex (Figure 1) (4). The crystal structure was obtained for $\mathrm{Ca}^{2+}$-loaded ALG- 2 following digestion with elastase to remove residues 1-20. A decapeptide, consisting of multiple glycine and proline residues and likely originating from a portion of the digested N-terminus of ALG-2, was found bound to a hydrophobic cleft between the N- and C-terminal halves of ALG-2. Binding of $\mathrm{Ca}^{2+}$ purportedly exposes the hydrophobic cleft, allowing binding of its $\mathrm{N}$-terminal region to the newly formed pocket; this then supposedly induces a substantial conformational change in ALG-2, triggering target recognition and binding.

Two groups $(6,7)$ have independently identified the target protein for ALG-2, Alix or AIP1. Alix/AIP1 is a cytoplasmic protein $\sim 98 \mathrm{kDa}$ in size, containing a proline-rich C-terminal region encompassing several Src homology domain 3 (SH3) binding motifs. This region was shown to interact with SETA (SH3 domain expressed in tumorigenic astrocytes) (8), whereby Alix/ AIP1 could mediate UV light-induced cell death in astrocytes. Alix/AIP1 has also been implicated in multivesicular sorting mediated by the interactions of the N-terminal region of the protein with CHMP4b (9), while the C-terminal region is associated with ALG-2 interactions. It has been proposed that Alix/AIP1 could form a molecular link between endosomal sorting and cell death pathways (10).

The coimmunoprecipitation of ALG- 2 with Alix/AIP1 requires $\mathrm{Ca}^{2+}$ concentration in the submicromolar range (7). Two isoforms of ALG-2 have been reported in mouse tissues; one form lacks two amino acids (G121 and F122), has different $\mathrm{Ca}^{2+}$-binding properties from the longer version, and does not interact with Alix/AIP1 (11). In Dictyostelium, two isoforms of ALG-2 also were identified, displaying differences in the length of their N-terminal non-PEF regions. Only the isoform with the shorter $\mathrm{N}$-terminal region could interact with Alix/AIP1 (12).

Here, we demonstrate that in uveal melanoma, the most common primary tumor originating in the adult eye, melanoma cells down-regulate $A L G-2$, thereby imbuing some selective advantage upon these cells. In an attempt to understand the effect of $\mathrm{Ca}^{2+}$ on the structure and interactions of ALG-2, we have determined the conditions for dimer formation, the cellular localization of ALG-2 and Alix/AIP1, the roles of the N-terminal region and the functional EF

${ }^{1}$ Abbreviations: ER, endoplasmic reticulum; PEF, penta-EF-hand; GAPDH, glyceraldehyde-3-phosphate dehydrogenase; IPTG, isopropyl- $\beta$-D-thiogalactopyranoside 
hands of ALG-2 on $\mathrm{Ca}^{2+}{ }_{-}$-induced conformational changes, and their effect on subsequent interactions with Alix/AIP1. These studies are critical for understanding how $\mathrm{Ca}^{2+}$ initiates recognition between a member of the family of PEF proteins and its target.

\section{MATERIALS AND METHODS}

Cell Culture. Cells were cultured as previously described (13). Briefly, Mel290 cells were established from a biopsy of human uveal melanoma and maintained in RPMI-1640 medium supplemented with $10 \%$ fetal bovine serum, $10 \mathrm{mM}$ HEPES, penicillin $(100 \mathrm{U} / \mathrm{ml})$, streptomycin $(100 \mu \mathrm{g} / \mathrm{mL})$, and $0.1 \%$ amphotericin B. Normal uveal melanocytes were obtained from human donor eyes and kept in short-term cultures according to published procedures (14).

RNase Protection Assay. ALG-2 transcript levels were compared in uveal melanocytes and Mel290 cells by RNase protection assay using 250 base antisense ALG-2 riboprobes and a 177 base antisense glyceraldehyde-3-phosphate dehydrogenase (GAPDH) riboprobe as an internal standard. Methods were described previously (13).

Expression and Purification of Full-Length ALG-2 and dNALG-2. ALG-2 exons were amplified using the primers 5'-CCG CGA ACA TAT GGC CGC CTA CTC TTA CCG-3' and 5'-GCG GCG GAT CCG TTG TGC TGC TCT TCA CGA GA-3' from cDNA derived from uveal melanocytes and cloned into pCR2.1 using a TA cloning kit (Invitrogen). The insert containing the correct sequence was isolated and purified after restriction digestion with NdeI and BamHI and then cloned into the pET3a expression system. Recombinant protein was expressed in Escherichia coli strain BL21(DE3) cells. Cells in LB media containing $100 \mu \mathrm{g} /$ $\mathrm{mL}$ ampicillin were grown to an $\mathrm{OD}_{600}$ of 0.6 and then induced with $0.4 \mathrm{mM}$ IPTG and grown overnight at $25^{\circ} \mathrm{C}$. ALG-2 protein was purified from bacterial pellets using methods previously described (3). ALG-2 partitioned to the soluble fraction after extraction of the post-French press bacterial pellet with $10 \mathrm{mM}$ Tris, pH 7.5, containing $1 \mathrm{mM}$ EDTA. ALG-2 was further enriched and purified using an ion-exchange FPLC column (Mono Q, Pharmacia) and $\mathrm{NaCl}$ gradient for elution. Protein was quantified spectrophotometrically. The $\mathrm{N}$-terminal deletion mutant construct of ALG-2 (dNAlg-2), corresponding to residues 21-191, was obtained by PCR amplification of purified pET3aAlg-2 plasmid using the primers 5'-GCC CAT ATG GCG CTG CCG GAC CAG AGC-3' and 5'-GCG GCG GAT CCG TTG TGC TGC TCT TCA CGA GA-3'. The PCR product was cloned, expressed, and purified using the same methods as for full-length ALG-2.

Expression and Purification of Alix/AIP1. The N-terminal GST (glutathione S-transferase)tagged Alix/AIP1 clone was obtained from Dr. R. Sadoul (Universitè Joseph-Fourier, Pavillon de Neurologie, Centre Hospitalier Universitaire de Grenoble). The protein was expressed in bacteria, the GST-tag was cleaved using the Pre-scission protease (Amersham) according to the manufacturer's recommendations, and Alix/AIP1 was purified by affinity chromatography as described previously (12).

Site-Directed Mutagenesis of ALG-2. The ALG-2 mutants E114D, E47D, D169A, and dF122 were made using the Quickchange site-directed mutagenesis kit (Stratagene) according to the manufacturer's instructions. Complementary primers used were as follows: for E114D, 5'ATGATCGATAAGAACGACCTGAAGCAGGCCCTC-3' and 5'GAGGGCCTGCTTCAGGTCGTTCTTATCGATCAT-3'; for E47D, 5'GTGATATCAGACA CCGACCTTCAGCAAGCTCTC-3' and 5'GAGAGCTTGCTGAAGGTCGGTGTCTGATATCAC-3'; for D169A, 5'ATATTCAGACGTTACGCCACGGATCAGGACGGC-3' and 5'GCCGTCCTGATCCGTGGCGTAAC GTCTGAATAT-3'; for dF122, 5'- 
CTCTCAGGTGGCTACCGGCTCTCTGACCAGTTC-3' and 5'-GA

ACTGGTCAGAGAGCCGGTAGCCACCTGAGAG-3'. The two complementary primers used were extended during temperature cycling using $P f u$ Turbo DNA polymerase with pET3aALG-2 as the template. Following $D p n I$ digestion of the parental cDNA, the preparation was transformed into XL1-blue supercompetent cells. Cycling parameters used were $30 \mathrm{~s}$ at $95^{\circ} \mathrm{C}$ and 12 cycles of $30 \mathrm{~s}$ at $95^{\circ} \mathrm{C}, 1 \mathrm{~min}$ at $55^{\circ} \mathrm{C}, 10 \mathrm{~min}$ at $68^{\circ} \mathrm{C}$. Plasmids from sequenced clones were then transformed into BL21pLysS(DE3) and expressed and purified using the same methods used for full-length ALG-2.

Preparation of Affinity-Purified Antibodies. Antibodies to recombinant full-length ALG-2 were raised in rabbits following published procedures (15). The immunoreactive serum was purified on an affinity column whereby ALG-2 was immobilized on CNBr-activated Sepharose beads (Pharmacia). Polyclonal rabbit antibodies to a peptide derived from the Alix/AIP1 sequence, LDEEATDNDLRAK, were purified similarly. Antibodies to ALG-2 protein were also raised in rats, and the antiserum was used directly for the detection of ALG-2.

Immunoblotting Analysis. Proteins were resolved using 15\% SDS-polyacrylamide gel electrophoresis and transferred to poly(vinylidene difluoride) membranes (Immobilon-P, Millipore). Blots were blocked with 5\% BSA and 5\% nonfat dry milk in TBST, pH 8.0. Primary antibody incubations were carried out for $1 \mathrm{~h}$ at room temperature followed by $1 \mathrm{~h}$ incubation with an HRP-conjugated anti-immunoglobulin (Jackson Immunoresearch Lab.). Bands were visualized using the enhanced chemiluminescence system (ECL, Amersham) and exposure to X-ray film.

Immunocytochemistry. Staining of fixed cells was carried out as previously described (16). Rat anti-ALG-2 and rabbit anti-Alix/AIP1 were used as primary antibodies followed by Texas red conjugated anti-mouse (Amersham) and FITC conjugated anti-rabbit (Vector Lab.) secondary antibodies. Cells were viewed with a Zeiss Axiophot microscope.

Cellular Cross-Linking of ALG-2. Mel290 cells $\left(5 \times 10^{6}\right)$ were incubated for $30 \mathrm{~min}$ at room temperature in Hank's balanced salt solution containing the amino-reactive, cleavable crosslinker dithiobis[succinimidylpropionate] (1 mM DSP, Pierce) after 15 min pretreatment with either $10 \mu \mathrm{M}$ thapsigargin or $1 \mathrm{mM}$ EDTA at room temperature. Cells were scraped and lysed in $10 \mathrm{mM}$ Tris, $10 \mathrm{mM} \mathrm{NaCl}$, pH 7.5, containing protease inhibitors. Lysates were analyzed by immunoblotting under reducing and nonreducing conditions and probed with anti-ALG-2 antibodies.

Sedimentation Equilibrium of ALG-2 and dNALG-2. Protein samples at 5, 10, and $20 \mu \mathrm{M}$ prepared in Chelex-treated $10 \mathrm{mM}$ Tris, $\mathrm{pH} 7.5$ containing $150 \mathrm{mM} \mathrm{NaCl}$ (with or without 1 mM EDTA or containing $5 \mu \mathrm{M} \mathrm{CaCl}_{2}$ ) were analyzed in a Beckman Optima XL-A analytical centrifuge. Double sector charcoal-filled Epon centerpieces were used with path lengths of 12 $\mathrm{mm}$. Buffer was used as reference in one sector, and $105 \mu \mathrm{L}$ of sample was in the other. The concentration gradients were recorded at $280 \mathrm{~nm}$ every $2-4 \mathrm{~h}$ until the gradients became superimposable (after $\sim 12-16 \mathrm{~h}$ ). Initial absorbance values were recorded at $3000 \mathrm{rpm}$. Equilibrium data were collected at $9000,12000,16000$, and $22000 \mathrm{rpm}$ at $20^{\circ} \mathrm{C}$. Reversibility was checked at $12000 \mathrm{rpm}$ by reducing the speed after equilibrium had been reached at 22000 $\mathrm{rpm}$. At the end of the run, sample depletion was carried out at $42000 \mathrm{rpm}$ to obtain baseline absorbance values for each cell. The molecular weight and partial specific volume were calculated from the amino acid sequence to be 21454 and 0.727 , respectively, for full-length ALG-2 (determined to be residues 3-189 by mass spectrometric analysis) and 20067 and 0.727 for dNALG-2 (residues 21-191). The extinction coefficient for ALG-2 was determined and found to match the reported value of $39200 \mathrm{M}^{-1} \mathrm{~cm}^{-1}$. The buffer density was measured with an Anton Paar DMA5000 density meter and found to be $1.003 \mathrm{~g} / \mathrm{mL}$ at $20^{\circ} \mathrm{C}$. 
A program written for Igor Pro (Wavemetrics Inc., Lake Oswego, OR) by Darrell R. McCaslin (Biophysics Instrumentation Facility, UW Madison) was used for the analysis of the sedimentation equilibrium data. Prior to analysis, all data sets were corrected for baseline absorbance as determined from the values obtained after protein depletion. All data sets (three concentrations each at four speeds) were fit simultaneously to a single species (monomer) and an oligomeric model.

Flow Dialysis. Metal-free protein samples were prepared by incubating the concentrated proteins with $100 \mu \mathrm{M}$ EGTA followed by Sephadex G-25 gel filtration in a buffer containing $50 \mathrm{mM}$ Tris- $\mathrm{HCl}, \mathrm{pH} \mathrm{7.5}$, and $150 \mathrm{mM} \mathrm{KCl}$. The protein concentration was measured spectrophotometrically using a molar extinction coefficient at $278 \mathrm{~nm}$ of $39670 \mathrm{M}^{-1} \mathrm{~cm}^{-1}$. $\mathrm{Ca}^{2+}$ binding was measured at $25^{\circ} \mathrm{C}$ by flow dialysis using $20-25 \mu \mathrm{M}$ protein (17). Experiments were carried out in the presence of $0.5 \%$ Tween 20 to prevent protein precipitation as previously published (18). Detergent was present in both the stationary protein compartment and the perfusate. Treatment of the raw data and evaluation of the intrinsic metal-binding constants have been described elsewhere (19).

Surface Plasmon Resonance. Real-time binding analysis was performed at $25^{\circ} \mathrm{C}$ using an SPR biosensor, BIAcore system (Biacore, Uppsala, Sweden), and methods previously described $(12,20)$. The amount of immobilized Alix/AIP1 corresponded to 14000 resonance units. Running buffer for protein interaction contained $20 \mathrm{mM}$ Tris, $150 \mathrm{mM} \mathrm{NaCl}, \mathrm{pH} 7.5$, and $0.005 \%$ surfactant P-20 (BIACORE). Flow rate was maintained at $20 \mu \mathrm{L} / \mathrm{min}$. Reference sensorgrams for subtraction of bulk refractive index background were obtained by running protein over an unimmobilized flow cell. Surfaces were regenerated by injecting $100 \mu \mathrm{L}$ of 1 mM EDTA. Association studies were carried out with $60 \mu \mathrm{L}$ of sample followed by $120 \mathrm{~s}$ of dissociation either with buffer containing $\mathrm{Ca}^{2+}$ (COINJECT program) or with running buffer (KINJECT program).

TNS Fluorescence Measurements. Fluorescence measurements were carried out using 2-( $p$ toluidino)naphthalene-6-sulfonate (TNS) fluorescence enhancement. All fluorescence measurements were recorded at room temperature with a Shimadzu RF-5301PC spectrofluorometer in $20 \mathrm{mM}$ Tris, $150 \mathrm{mM} \mathrm{NaCl}, \mathrm{pH}$ 7.5. Typically $500 \mu \mathrm{L}$ of buffer containing $2 \mu \mathrm{M}$ protein and $10 \mu \mathrm{M}$ TNS with or without added $\mathrm{Ca}^{2+}$ or EDTA was used. Excitation wavelength was set at $340 \mathrm{~nm}$ and emission spectra were measured from 350 to 550 $\mathrm{nm}$. Fluorescence intensity values were measured at $436 \mathrm{~nm}$.

\section{RESULTS}

Expression of ALG-2 in Uveal Melanoma. Initial subtractive hybridization experiments indicated that the expression of $A L G-2$ is diminished in Mel290, a uveal melanoma cell line, compared with uveal melanocytes (UM), the normal progenitor cells (data not shown). To verify these findings, $A L G-2$ mRNA levels were compared by RNAse protection assay using an antisense probe specific for ALG-2 (Figure 2A). Lower amounts of ALG-2 mRNA were detected in the Mel290 cells. These results extended to protein levels as well, determined by immunoblotting of whole cell extracts (Figure 2B). Mel290 cells therefore down-regulate the $\mathrm{Ca}^{2+}$-binding, proapoptotic protein ALG-2, consistent with findings from the original subtractive hybridization studies.

Localization of ALG-2 and Alix/AlP1. The cytoplasmic localization of ALG-2 was previously demonstrated in 3DO cells, a mouse T cell hybridoma line (1), while in a subpopulation of Jurkat cells and certain lung and breast cancer cells ALG-2 showed nuclear staining (2l). ALG-2 also was localized to the nuclei of transiently transfected BOSC23 cells (22). To clarify the cellular localization of ALG-2 and its putative target protein Alix/AIP1, UM and Mel290 cells were analyzed by double-label immunocytochemistry. In UM cells (Figure 3A) and 
Mel290 cells (Figure 3C), ALG-2 localized predominantly to the cytoplasm with additional perinuclear staining. Alix/AIP1 demonstrated the same subcellular distribution as ALG-2 in colocalization studies of UM and melanoma cells (Figure 3B,D, respectively).

A subset of UM and Mel290 cells also displayed nuclear staining for both ALG-2 and Alix/ AIP1. Costaining with Hoechst dye demonstrated that ALG-2 redistributes throughout the cell during metaphase, following break-down of the nuclear membrane, except to regions occupied by condensed chromosomes (Figure 3E,F).

Other studies have suggested that the distribution of ALG-2 may depend on the $\mathrm{Ca}^{2+}$ concentration. To test this proposal in UM and Mel290 cells, we fixed and immunostained cells for the distribution of ALG-2 in the presence of added $\mathrm{Ca}^{2+}$ or EDTA (Figure 4A,B). ALG-2 remained cytoplasmic under both conditions in both cell types. Thapsigargin and ionomycin, known $\mathrm{Ca}^{2+}$-mobilizing agents, and apoptotic agents, such as staurosporin, were used to determine whether elevation of intracellular $\mathrm{Ca}^{2+}$ or induction of apoptosis would cause the redistribution of ALG-2. None of these conditions affected the localization of ALG-2 (data not shown).

Dimerization of ALG-2. To determine whether ALG-2 exists as a dimer at cellular concentrations under high and low $\mathrm{Ca}^{2+}$ concentration, Mel290 cells were treated with the cellpermeable, reversible cross-linker DSP after preincubation with either thapsigargin to increase intracellular free $\mathrm{Ca}^{2+}$ concentration or EDTA. The cells were then lysed, and proteins were separated by gel electrophoresis. Following treatment with thapsigargin, bands containing ALG-2 were identified by Western blotting using anti-ALG-2 antibodies (Figure 5A, lane 1). A $42 \mathrm{kDa}$ band was observed under nonreducing conditions. The size of the cross-linked product suggests the formation of dimer. In the presence of reducing agent, $\beta$-mercaptoethanol, the cross-linker was cleaved, and ALG-2 assumed the mobility of a $21 \mathrm{kDa}$ protein, corresponding to the monomer (Figure 5A, lane 2). Similar results were obtained with cells treated with EDTA (data not shown). These findings suggest that ALG-2 forms dimers at cellular concentrations, and dimer formation is unaffected by changes in the intracellular $\mathrm{Ca}^{2+}$ concentration.

To determine whether ALG-2 forms dimers in the absence of $\mathrm{Ca}^{2+}$ and other cellular components, recombinant ALG-2 was expressed. Analytical centrifugation studies were conducted with the purified protein in the presence of EDTA. The average molecular weight calculated from the equilibrium data obtained from three different protein concentrations (5$20 \mu \mathrm{M}$ ) at four speeds suggest that ALG-2 exists predominantly as a dimer (expected $=42908$, observed $=38$ 910) at the concentrations used for the analysis (Figure 5B). The lower concentration samples and those at higher speeds had lower average molecular weights suggesting increased monomer content. On the basis of the dissociation constant obtained from the simulations, at protein concentrations less than $1 \mu \mathrm{M}$, ALG-2 exists in equilibrium between monomer and dimer.

In the presence of $\mathrm{Ca}^{2+}$, purified ALG-2 tends to form aggregates and precipitate at concentrations required for analytical centrifugation. Deletion of the N-terminal region of ALG-2 improves its solubility in the presence of $\mathrm{Ca}^{2+}$ (5). dNALG-2, the truncated form of ALG-2 comprised of amino acids 21-191, therefore, was cloned and expressed. Analytical centrifugation experiments both in the presence $\left(5 \mu \mathrm{M} \mathrm{Ca}^{2+}\right)$ and absence ( $1 \mathrm{mM}$ EDTA) of $\mathrm{Ca}^{2+}$ were then conducted. Observed average molecular weights were 40505 and 39 626, respectively (expected dimer weight $=40128$ ). Results from these experiments support a single-species dimer model independent of $\mathrm{Ca}^{2+}$ (Figure 5C).

Interaction with Alix/AIP1. Surface plasmon resonance (SPR) has been used successfully to look at the interaction between Dictyostelium discoideum ALG-2 and murine Alix/ AIP1 
(12). We examined the in vitro interaction between human ALG-2 and Alix/AIP1 to determine regions of interaction and the $\mathrm{Ca}^{2+}$ dependency of their interaction. Purified Alix/AIP1 was immobilized on the surface of a CM5 chip (Biacore). ALG-2 interaction with Alix/AIP1 was compared in the presence and absence of $\mathrm{Ca}^{2+}$ (Figure 6A). No interaction was observed in the presence of EDTA, and the response was similar to the control flow cell containing no immobilized Alix/AIP1. However, in the presence of $\mathrm{Ca}^{2+}$, there was an increased response to ALG-2 in the flow cell containing Alix/AIP1. Removal of both protein and $\mathrm{Ca}^{2+}$ resulted in the rapid dissociation of the complex as can be seen in Figure 6A. The relative response, measured at the plateau of the sensorgrams, increased as a function of both protein concentration (Figure 6B) and $\mathrm{Ca}^{2+}$ concentration (Figure 6C) until saturation was reached at $\sim 1000 \mathrm{nM}$ ALG-2 in the presence of $50 \mu \mathrm{M} \mathrm{Ca}^{2+}$ or $400 \mathrm{nM}$ ALG-2 in the presence of 100 $\mu \mathrm{M} \mathrm{Ca}^{2+}$.

Deletion of F122, a residue absent in a noninteracting ALG-2 isoform identified in mice (18), markedly reduced the affinity for Alix/AIP1 and served as a negative control (Figure 8A).

These data collectively demonstrate that the interaction between ALG-2 and Alix/AIP1 is specific and depends on $\mathrm{Ca}^{2+}$ concentration.

Effect of $\mathrm{Ca}^{2+}$ Binding to Functional EF Hands. To determine which $\mathrm{Ca}^{2+}$-binding sites are essential for the interaction of ALG-2 with Alix/AIP1, site-directed mutagenesis was performed to replace critical $\mathrm{Ca}^{2+}$-coordinating residues within the reported functional $\mathrm{EF}$ hands of ALG-2 (4,5,18). Mutants were generated with single amino acid substitutions at glutamate residues in the consensus sequences within EF-1 and EF-3, converting them to aspartate residues (E47D and E114D, respectively). As shown in other EF-hand-type calciumbinding proteins, replacement of glutamate, contributing two oxygens to the coordination of $\mathrm{Ca}^{2}$, with a shorter aspartate increases the rate of $\mathrm{Ca}^{2+}$ dissociation and lowers overall affinity without affecting electrostatic charge requirements for loop stability $(23,24)$. In addition to these reported high-affinity sites, the aspartate in EF-5, the purported low-affinity site, was replaced with an alanine (D169A). CD measurements of mutants when compared to ALG-2 show superimposable molar ellipticity spectra indicating that mutants retained their secondary structure (data not shown).

Flow dialysis confirmed that wild-type ALG-2 possesses two high-affinity $\mathrm{Ca}^{2+}$-binding sites and one low-affinity site (Figure 7), as published previously (18). In contrast, the E47D mutant possesses only one high-affinity site, suggesting that EF-1 is a normal high-affinity site in ALG-2. The substitution of glutamate for aspartate in position 12 of the first $\mathrm{Ca}^{2+}$-chelating loop corresponding to EF-1 does not eliminate but lowers the affinity for $\mathrm{Ca}^{2+}$ by a factor of $30\left(K_{2}{ }^{\prime}(\mathrm{ALG}-2)=4.0 \times 10^{5} ; K_{2}{ }^{\prime}(\mathrm{E} 47 \mathrm{D})=1.3 \times 10^{4}\right)$. The affinities of the remaining two sites are not $\times$ significantly altered by this mutation. The mutation E114D leads to more profound alterations in the $\mathrm{Ca}^{2+}$-binding properties of ALG-2. Only two binding sites can be titrated (Figure 7), and the affinities of these sites are lower than the high-affinity sites in the wild-type protein $\left(K_{1}{ }^{\prime}(\mathrm{ALG}-2)=5.3 \times 10^{5}, K_{2}{ }^{\prime}(\mathrm{ALG}-2)=4.0 \times 10^{5} ; K_{1}{ }^{\prime}(\mathrm{E} 114 \mathrm{D})=8.0 \times 10^{4}, K_{2}{ }^{\prime}(\mathrm{E} 114 \mathrm{D})\right.$ $\left.=3.0 \times 10^{4}\right)$. Thus it seems that this mutation simultaneously weakens $\mathrm{Ca}^{2+}$ binding to EF-1 and EF-3 and abolishes the low-affinity site. The binding curve of E114D shows negative cooperativity, and we suppose that EF-3 displays the lower intrinsic affinity constant of the two $\left(3.0 \times 10^{4}\right)$. At the concentrations of calcium $(10-50 \mu \mathrm{M})$ used in subsequent experiments, the curves in Figure 7 demonstrate that wild-type ALG- 2 binds 2 mol of $\mathrm{Ca}^{2+}$ per mole of protein, while the E47D and E114D mutants bind only $1 \mathrm{~mol}$ of $\mathrm{Ca}^{2+}$ per mole of protein. The $\mathrm{Ca}^{2+}$-binding properties of the mutant D169A are quite similar to that of the wild-type ALG-2 (Figure 7). 
These mutants were then compared with ALG-2 for their ability to interact with Alix/AIP1 (Figure $8 \mathrm{~B}$ ). At $\mathrm{Ca}^{2+}$ concentration concentrations of $50 \mu \mathrm{M}$, corresponding to the two highaffinity sites being occupied in ALG-2 and one site in E47D and E114D (Figure 7), the mutants lacked significant interaction with Alix/AIP1, comparable to responses using the unimmobilized flow cell. D169A had a lower response in the presence of $\mathrm{Ca}^{2+}$ than full-length ALG-2 but more than the baseline signal obtained for the EF-1 and EF-3 mutants. Experiments could not be conducted at higher concentrations of calcium in an attempt to occupy additional calcium-binding sites in mutant forms of ALG-2 owing to protein precipitation that occurs at elevated levels of calcium in the absence of detergent.

Effect of the N-Terminal Non-PEF Region on Interactions with Alix/AIP1. Studies of the crystal structure of a truncated form of ALG-2 (residues 21-191) suggested that the binding of the Nterminal region of ALG-2 to a hydrophobic pocket occurs upon $\mathrm{Ca}^{2+}$ binding to EF-1 and EF-3 (Figure 1) (4). The folding of the N-terminal region into the hydrophobic pocket then causes a hinge effect, opening the molecule for target recognition. This model would suggest that the absence of the N-terminal region might prevent or attenuate the interaction of ALG-2 with the target molecule. To further test the model, the interaction of the N-terminal deletion mutant (dNALG-2) with Alix/AIP1 was studied using SPR. In the presence of $\mathrm{Ca}^{2+}$, the response obtained with dNALG-2 was comparable to full-length ALG-2 for immobilized Alix/AIP1. Further, the addition of peptides corresponding to residues 7-17 (Figure 8C) and the deleted N-terminal portion, residues 1-22 (data not shown), to either dNALG-2 or ALG-2 had no effect on the interaction with Alix/AIP1. These results suggest that regions other than the N-terminal portion of ALG-2 interact with Alix/AIP1, and the N-terminal region does not enhance the binding of ALG-2 to Alix/AIP1.

$\mathrm{Ca}^{2+}$-Induced Conformational Changes in $A L G-2$. The $\mathrm{Ca}^{2+}$-induced conformational changes in ALG-2 and mutants were studied by examining fluorescence emission spectra in the presence of TNS. These experiments were carried out to investigate whether changes in surface hydrophobicity correlated with affinity for the target molecule, Alix/AIP1, as determined by SPR. In the presence of $\mathrm{Ca}^{2+}$, ALG-2 showed a marked increase in fluorescence, similar to results obtained with mouse ALG-2 (5). Deletion of the N-terminal region had little effect on this $\mathrm{Ca}^{2+}$-induced fluorescence change (Figure 9A). Both full-length and truncated forms of ALG-2 showed maximum fluorescence intensity at $40 \mu \mathrm{M} \mathrm{Ca}^{2+}$ and saturation at higher $\mathrm{Ca}^{2+}$ concentration. Based on the flow data, this concentration is suggestive of only the highaffinity sites being occupied. As with the interaction with Alix/AIP1, there was no consequence of addition of the $\mathrm{N}$-terminal peptides (residues 7-17 or 1-21) to the $\mathrm{Ca}^{2+}$-induced TNS fluorescence changes of dNALG-2 or full-length ALG-2 (data not shown). These results correlate with the results from SPR studies where deletion of the N-terminal region had little effect on the interaction with Alix/AIP1.

SPR results clearly indicate that interference with $\mathrm{Ca}^{2+}$ binding at both EF-1 and EF-3 significantly compromises the interaction with Alix/AIP1 and that the D169A mutation also has a moderate effect. TNS fluorescence experiments were carried out with the mutants of ALG-2, E47D (EF-1), E114D (EF-3), and D169A (EF-5) in the absence (1 mM EDTA) and presence of $60 \mu \mathrm{M} \mathrm{Ca}^{2+}$. Mutation in EF-3 completely abrogated the $\mathrm{Ca}^{2+}$-induced hydrophobicity changes detectable by TNS fluorescence (Figure 9B), correlating with the lack of interaction of this mutant with Alix/AIP1. In contrast, the EF-1 mutation only slightly reduced the TNS fluorescence signal upon the addition of $\mathrm{Ca}^{2+}$. The D169A mutation resulted in an intermediate $\mathrm{Ca}^{2+}$-induced fluorescence change. Results suggest that the most significant conformational change, detectable by TNS fluorescence changes, arises from $\mathrm{Ca}^{2+}$ binding to EF-3. 


\section{DISCUSSION}

In addition to unregulated cell growth, disruption of apoptosis may be important during tumor growth and metastasis. More malignant tumor cells may be selected owing to their higher expression of antiapoptotic factors or their down regulation of proapoptotic genes $(25,26)$. $\mathrm{Ca}^{2+}$ plays a significant role in apoptosis and mediates at least a portion of its function through the action of $\mathrm{Ca}^{2+}$-binding proteins (27). In uveal melanoma, we demonstrate the differential expression of $A L G-2$, a gene identified as a $\mathrm{Ca}^{2+}$-dependent regulator of apoptosis. Mel290 cells derived from a human tumor were found to express lower levels of ALG-2 mRNA and protein than normal uveal melanocytes. The down regulation of ALG-2 suggests one way by which these cells may achieve a selective advantage, by interfering with $\mathrm{Ca}^{2+}$-mediated apoptotic signals and thereby enhancing cell survival.

Krebs et al. (28) compared the expression of ALG-2 in cell extracts obtained from biopsies of normal and malignant tissues from the same patient. Unlike uveal melanoma, a significant increase in ALG-2 expression in the cancerous tissues from different lung and breast tumors was reported. Immunohistochemistry of the lung carcinomas in those studies showed intense ALG-2 staining largely localized to the nuclei of tumor cells. However, some commercial antiALG-2 antibodies have been found by this and other laboratories $(29,30)$ to recognize a protein of the same size as ALG-2 but to be unable to recognize the recombinant protein. We therefore generated polyclonal antibodies to purified and sequenced human ALG-2 and used them for immunoblotting and immunohistochemical analyses. ALG-2 was found to localize to the cytoplasm of UM and melanoma cells independent of $\mathrm{Ca}^{2+}$ concentration or activation of programmed cell death. Treatment of these cells with thapsigargin, a drug known to release calcium from intracellular stores and cause cell death through ER stress with potential ALG-2 involvement (2), did not result in any change in localization of ALG-2. The contrast in findings between our studies and others $(21,28,29)$ may be due to the different cancer cell types being examined or the fidelity of the antibodies used in the studies (30).

Various biochemical and structural approaches have been used to characterize different ALG-2 analogues $(3,4,12,18,20,31)$. As with other members of this family of $\mathrm{Ca}^{2+}$-binding proteins, ALG-2 exists as a dimer in solution $(32,33)$. From our studies, dimer formation is independent of $\mathrm{Ca}^{2+}$ and is unaffected by the deletion of the $\mathrm{N}$-terminal region. The role of the $\mathrm{N}$-terminal non-EF-hand region of ALG-2 might vary between species. The ALG-2 isoforms in Dictyostelium were found to require the $\mathrm{N}$-terminal region for both dimer formation and interaction (12). Both ALG-2 forms had longer N-terminal regions than mouse or human ALG-2. In the case of human ALG-2, deletion of the N-terminal region improved the solubility of the protein in the presence of $\mathrm{Ca}^{2+}$. The deletion, however, did not affect dimer formation, consistent with the involvement of the $\mathrm{C}$-terminal region in this process based on the crystal structure (Figure 1) (4). Deletion of the N-terminal region also did not significantly affect the $\mathrm{Ca}^{2+}$-induced conformational change as observed by TNS fluorescence measurements. $\mathrm{Ca}^{2+}$ dependent interaction with Alix/AIP1 for full-length ALG-2 and dNALG-2 also were comparable. The N-terminal region of ALG-2 therefore might have more significant consequences in terms of its interactions with target molecules other than Alix/AIP1 in other cell types.

On the basis of the crystal structure of $\mathrm{Ca}^{2+}$-bound, elastase-digested ALG-2, it was suggested that the binding of $\mathrm{Ca}^{2+}$ resulted in the formation of a hydrophobic pocket, occupied by the Nterminal region of ALG-2 and causing a hinge-like effect, opening the molecule for target binding (4). TNS fluorescence and Alix/AIP1 interaction studies presented here show no difference between ALG-2 and dNALG-2 with or without the addition of exogenous peptides corresponding to the cocrystallized decapeptide derived from elastase treatment of ALG-2, as 
well as the entire $\mathrm{N}$-terminal peptide, suggesting that at least in the case of Alix/AIP1, the interaction mechanism does not involve the N-terminal region of human ALG-2.

Of the five EF-hands in ALG-2, EF-1 and EF-3 have been identified as the high-affinity $\mathrm{Ca}^{2+}$-binding sites $(4,5,18)$. The location of the low-affinity site is less well established. In the crystal structure, a third $\mathrm{Ca}^{2+}$ is bound to EF-5 (4), potentially due to artificially high concentrations of protein and $\mathrm{Ca}^{2+}$. Site-directed mutagenesis was used in the studies presented here to specifically alter a critical residue required for $\mathrm{Ca}^{2+}$ coordination in each of these $\mathrm{EF}$ hands. Flow dialysis data of the E47D mutant confirm that EF-1 comprises one of the highaffinity $\mathrm{Ca}^{2+}$-binding sites and the mutation effectively eliminates $\mathrm{Ca}^{2+}$ binding. In contrast, the concomitant decrease of both high-affinity sites in the E114D mutant is unexpected and points to a structural role of this residue. Flow dialysis data of E114D indicate a direct effect on EF-3, the second high-affinity $\mathrm{Ca}^{2+}$-binding site, and an indirect effect on EF-1. The relatively small difference in the binding curves of D169A and wild-type ALG-2, together with the fact that the low-affinity site is not abolished, suggest that the precise location of the latter site remains unresolved. The crystal structure of ALG-2 shows two $\mathrm{Ca}^{2+}$ ions bound to EF-3; perhaps the E114D mutation disables the binding of one ion but not the other. If the extra $\mathrm{Ca}^{2+}$ in EF-3 corresponds to the low-affinity site rather than EF-5, then this might explain the ineffectiveness of the D169A mutation in abolishing the low-affinity $\mathrm{Ca}^{2+}$-binding site. The physiological relevance of the low-affinity site, however, is unclear since occupancy requires millimolar $\mathrm{Ca}^{2+}$, unexpected in the cytosol.

Interestingly, the E47D and E114D mutations both resulted in loss of interaction with Alix/ AIP1. The D169A mutation, despite little change in $\mathrm{Ca}^{2+}$ affinity, also affected the interaction though not as significantly as the EF-1 and EF-3 mutants. The crystal structure (Figure 1) and studies on other members of the PEF family (34-38) indicate that this region is important for dimer formation. Residues from the F-helix of EF-5 also contribute to the hydrophobic pocket, potentially involved in target recognition. The reduced interaction might therefore result from the mutation in EF-5 impacting on other structural aspects important to the interaction of ALG-2 with Alix/AIP1 rather than influencing $\mathrm{Ca}^{2+}$-binding. This further supports a model whereby EF-1 and EF-3 are the functional $\mathrm{Ca}^{2+}$-binding sites in ALG- 2 and both sites have to be occupied for substantive interaction with Alix/AIP1.

The shorter aspartate in the E114D mutant may reorient the C-terminal $\alpha$-helix of EF-3, reshape the microenvironment around F122, and reduce hydrophobic exposure. TNS fluorescence results support this conclusion, whereby $\mathrm{Ca}^{2+}$ binding to EF-3 is essential for the conformational change resulting in the increased exposure of hydrophobic surfaces. Since both EF-1 and EF-3 are required for the interaction of ALG-2 with Alix/AIP1, $\mathrm{Ca}^{2+}$ binding to EF-1 might result in angle changes within the protein that are necessary for target recognition but do not significantly alter surface hydrophobicity.

In summary, we demonstrate that ALG-2 exists as a dimer in the cytoplasm of cells, independent of $\mathrm{Ca}^{2+}$ concentration, and undergoes conformational changes, including the increased exposure of hydrophobic surfaces through $\mathrm{Ca}^{2+}$ binding to EF-1 and EF-3. These conformational changes allow for target recognition and binding of Alix/AIP1. Based on the expression of putative target molecules in different cell types and physiological conditions, ALG-2 can mediate pathways involved in apoptosis (1), cell proliferation $(28,29)$, or both.

In uveal melanoma cells, reduced expression of ALG-2 likely favors cell survival through diminished apoptosis. Most current therapies are nonspecific and can result in considerable damage to normal tissue and have little impact on mortality, reaching more than $50 \%$ in highrisk melanoma patients (39-41). The characterization of biochemical pathways that can modulate cell death may lead to molecular therapies selectively targeting tumor cells. 


\section{ACKNOWLEDGMENT}

We would like to thank Dr. R. Stenkamp for his help with Figure 1 and Dr. D. R. McCaslin for his help with the analysis of the analytical centrifugation data.

\section{REFERENCES}

1. Vito P, Lacana E, D'Adamio L. Interfering with apoptosis: Ca(2+)-binding protein ALG-2 and Alzheimer's disease gene ALG-3. Science 1996;271:521-525. [PubMed: 8560270]

2. Rao RV, Poksay KS, Castro-Obregon S, Schilling B, Row RH, del Rio G, Gibson BW, Ellerby HM, Bredesen DE. Molecular components of a cell death pathway activated by endoplasmic reticulum stress. J. Biol. Chem 2004;279:177-187. [PubMed: 14561754]

3. Lo KWH, Zhang Q, Li M, Zhang MJ. Apoptosis-linked gene product ALG-2 is a new member of the calpain small subunit subfamily of $\mathrm{Ca}^{2+}$-binding proteins. Biochemistry 1999;38:7498-7508. [PubMed: 10360947]

4. Jia J, Tarabykina S, Hansen C, Berchtold M, Cygler M. Structure of apoptosis-linked protein ALG-2: insights into Ca2+-induced changes in penta-EF-hand proteins. Structure (Cambridge) 2001;9:267275.

5. Maki M, Yamaguchi K, Kitaura Y, Satoh H, Hitomi K. Calcium-induced exposure of a hydrophobic surface of mouse ALG-2, which is a member of the penta-EF-hand protein family. J. Biochem. (Tokyo) 1998;124:1170-1177. [PubMed: 9832622]

6. Missotten M, Nichols A, Rieger K, Sadoul R. Alix, a novel mouse protein undergoing calciumdependent interaction with the apoptosis-linked-gene 2 (ALG-2) protein. Cell Death Differ 1999;6:124-129. [PubMed: 10200558]

7. Vito P, Pellegrini L, Guiet C, D'Adamio L. Cloning of AIP1, a novel protein that associates with the apoptosis-linked gene ALG-2 in a $\mathrm{Ca}^{2+}$-dependent reaction. J. Biol. Chem 1999;274:1533-1540. [PubMed: 9880530]

8. Chen B, Borinstein SC, Gillis J, Sykes VW, Bogler O. The glioma-associated protein SETA interacts with AIP1/Alix and ALG-2 and modulates apoptosis in astrocytes. J. Biol. Chem 2000;275:1927519281. [PubMed: 10858458]

9. Katoh K, Shibata H, Suzuki H, Nara A, Ishidoh K, Kominami E, Yoshimori T, Maki M. The ALG-2interacting protein Alix associates with CHMP4b, a human homologue of yeast Snf7 that is involved in multivesicular body sorting. J. Biol. Chem 2003;278:39104-39113. [PubMed: 12860994]

10. Trioulier Y, Torch S, Blot B, Cristina N, Chatellard-Causse C, Verna JM, Sadoul R. Alix, a protein regulating endosomal trafficking, is involved in neuronal death. J. Biol. Chem 2004;279:2046-2052. [PubMed: 14585841]

11. Tarabykina S, Moller AL, Durussel I, Cox J, Berchtold MW. Two forms of the apoptosis-linked protein ALG-2 with different $\mathrm{Ca}^{2+}$ affinities and target recognition. J. Biol. Chem 2000;275:1051410518. [PubMed: 10744743]

12. Aubry L, Mattei S, Blot B, Sadoul R, Satre M, Klein G. Biochemical characterization of two analogues of the apoptosis-linked gene 2 protein in Dictyostelium discoideum and interaction with a physiological partner in mammals, murine Alix. J. Biol. Chem 2002;277:21947-21954. [PubMed: 11927596]

13. Walker TM, Van Ginkel PR, Gee RL, Ahmadi H, Subramanian L, Ksander BR, Meisner LF, Albert DM, Polans AS. Expression of angiogenic factors Cyr61 and tissue factor in uveal melanoma. Arch. Ophthalmol 2002;120:1719-1725. [PubMed: 12470148]

14. Hu DN, McCormick SA, Orlow SJ, Rosemblat S, Lin AY. Regulation of melanogenesis by human uveal melanocytes in vitro. Exp. Eye Res 1997;64:397-404. [PubMed: 9196391]

15. Polans AS, Palczewski K, Asson-Batres MA, Ohguro H, Witkowska D, Haley TL, Baizer L, Crabb JW. Purification and primary structure of Capl, an S-100-related calcium-binding protein isolated from bovine retina. J. Biol. Chem 1994;269:6233-6240. [PubMed: 8119967]

16. van Ginkel PR, Gee RL, Walker TM, Hu DN, Heizmann CW, Polans AS. The identification and differential expression of calcium-binding proteins associated with ocular melanoma. Biochim. Biophys. Acta Mol. Cell Res 1998;1448:290-297. 
17. Colowick SP, Womack FC. Binding of diffusible molecules by macromolecules: rapid measurement by rate of dialysis. J. Biol. Chem 1969;244:774-777. [PubMed: 5768868]

18. Tarabykina S, Moller AL, Durussel I, Cox J, Berchtold MW. Two forms of the apoptosis-linked protein ALG-2 with different $\mathrm{Ca}(2+)$ affinities and target recognition. J. Biol. Chem 2000;275:10514-10518. [PubMed: 10744743]

19. Cox, JA. Guidebook to the Calcium-binding Proteins. Celio, MR.; Paul, ST.; Schwaller, B., editors. Oxford University Press; Oxford, U.K: 1996. p. 1-12.

20. Satoh H, Shibata H, Nakano Y, Kitaura Y, Maki M. ALG-2 interacts with the amino-terminal domain of annexin XI in a $\mathrm{Ca}^{2+}$-dependent manner. Biochem. Biophys. Res. Commun 2002;291:1166-1172. [PubMed: 11883939]

21. Krebs J, Klemenz R. The ALG-2/AIP-complex, a modulator at the interface between cell proliferation and cell death? A hypothesis. Biochim. Biophys. Acta 2000;1498:153-161. [PubMed: 11108958]

22. Hwang IS, Jung YS, Kim E. Interaction of ALG-2 with ASK1 influences ASK1 localization and subsequent JNK activation. FEBS Lett 2002;529:183-187. [PubMed: 12372597]

23. Palczewski K, Polans AS, Baehr W, Ames JB. $\mathrm{Ca}^{2+}$-binding proteins in the retina: structure, function, and the etiology of human visual diseases. BioEssays 2000;22:337-350. [PubMed: 10723031]

24. Babu A, Su H, Ryu Y, Gulati J. Determination of residue specificity in the EF-hand of troponin C for $\mathrm{Ca}^{2+}$ coordination, by genetic engineering. J. Biol. Chem 1992;267:15469-15474. [PubMed: 1639788]

25. Green DR, Evan GI. A matter of life and death. Cancer Cell 2002;1:19-30. [PubMed: 12086884]

26. Soengas MS, Capodieci P, Polsky D, Mora J, Esteller M, Opitz-Araya X, McCombie R, Herman JG, Gerald WL, Lazebnik YA, Cordon-Cardo C, Lowe SW. Inactivation of the apoptosis effector Apaf-1 in malignant melanoma. Nature 2001;409:207-211. [PubMed: 11196646]

27. Hajnoczky G, Davies E, Madesh M. Calcium signaling and apoptosis. Biochem. Biophys. Res. Commun 2003;304:445-454. [PubMed: 12729578]

28. Krebs J, Saremaslani P, Caduff R. ALG-2: a Ca2+-binding modulator protein involved in cell proliferation and in cell death. Biochim. Biophys. Acta 2002;1600:68-73. [PubMed: 12445461]

29. la Cour JM, Mollerup J, Winding P, Tarabykina S, Sehested M, Berchtold MW. Up-regulation of ALG-2 in hepatomas and lung cancer tissue. Am. J. Pathol 2003;163:81-89. [PubMed: 12819013]

30. Mollerup J, Krogh TN, Nielsen PF, Berchtold MW. Properties of the co-chaperone protein p23 erroneously attributed to ALG-2 (apoptosis-linked gene 2). FEBS Lett 2003;555:478-482. [PubMed: 14675759]

31. Kitaura Y, Matsumoto S, Satoh H, Hitomi K, Maki M. Peflin and ALG-2, members of the penta-EFhand protein family, form a heterodimer that dissociates in a Ca2+-dependent manner. J. Biol. Chem 2001;276:14053-14058. [PubMed: 11278427]

32. Teahan CG, Totty NF, Segal AW. Isolation and characterization of grancalcin, a novel $28 \mathrm{kDa}$ EFhand calcium-binding protein from human neutrophils. Biochem. J 1992;286(Part 2):549-554. [PubMed: 1530588]

33. Hamada H, Okochi E, Oh-hara T, Tsuruo T. Purification of the Mr 22,000 calcium-binding protein (sorcin) associated with multidrug resistance and its detection with monoclonal antibodies. Cancer Res 1988;48:3173-3178. [PubMed: 3365700]

34. Jia J, Han Q, Borregaard N, Lollike K, Cygler M. Crystal structure of human grancalcin, a member of the penta-EF-hand protein family. J. Mol. Biol 2000;300:1271-1281. [PubMed: 10903868]

35. Kitaura Y, Satoh H, Takahashi H, Shibata H, Maki M. Both ALG-2 and peflin, penta-EF-hand (PEF) proteins, are stabilized by dimerization through their fifth EF-hand regions. Arch. Biochem. Biophys 2002;399:12-18. [PubMed: 11883899]

36. Hansen C, Tarabykina S, la Cour JM, Lollike K, Berchtold MW. The PEF family proteins sorcin and grancalcin interact in vivo and in vitro. FEBS Lett 2003;545:151-154. [PubMed: 12804766]

37. Maki M, Kitaura Y, Satoh H, Ohkouchi S, Shibata H. Structures, functions and molecular evolution of the penta-EF-hand Ca2+-binding proteins. Biochim. Biophys. Acta 2002;1600:51-60. [PubMed: 12445459]

38. Todd B, Moore D, Deivanayagam CC, Lin GD, Chattopadhyay D, Maki M, Wang KK, Narayana SV. A structural model for the inhibition of calpain by calpastatin: crystal structures of the native 
domain VI of calpain and its complexes with calpastatin peptide and a small molecule inhibitor. J. Mol. Biol 2003;328:131-146. [PubMed: 12684003]

39. Seddon JM, Gragoudas ES, Albert DM, Hsieh CC, Polivogianis L, Friedenberg GR. Comparison of survival rates for patients with uveal melanoma after treatment with proton beam irradiation or enucleation. Am. J. Ophthalmol 1985;99:282-290. [PubMed: 2983558]

40. Kath R, Hayungs J, Bornfeld N, Sauerwein W, Hoffken K, Seeber S. Prognosis and treatment of disseminated uveal melanoma. Cancer 1993;72:2219-2223. [PubMed: 7848381]

41. Bedikian AY, Legha SS, Mavligit G, Carrasco CH, Khorana S, Plager C, Papadopoulos N, Benjamin RS. Treatment of uveal melanoma metastatic to the liver - A review of the M D Anderson Cancer Center experience and prognostic factors. Cancer 1995;76:1665-1670. [PubMed: 8635073] 


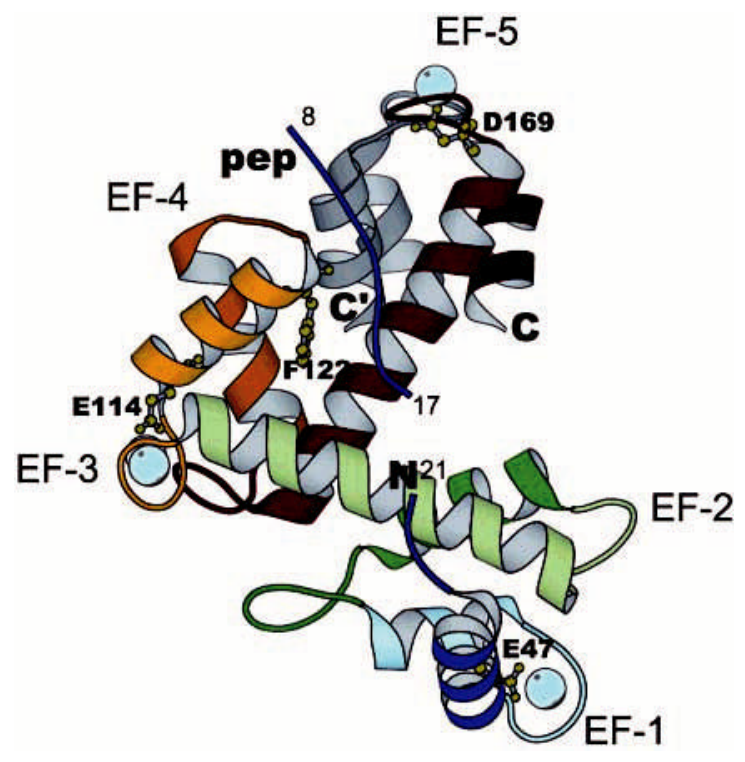

Figure 1.

Structural features of ALG-2. The model represents the structure of ALG-2 monomer (colored) with the C-terminal fragment from the second monomer (gray, $\mathrm{C}^{\prime}$ ), which in the crystal structure forms a part of the dimer interface between two monomers (Protein Data Bank: $1 \mathrm{HQV})$. The helices are depicted in the rainbow colors from the first helix in blue and the last in dark red. Treatment with elastase eliminates residues 1-7 and 18-20; however, decapeptide 8-17 (PGPGGGPGPA) remains bound to a hydrophobic cleft formed by EF-4 and the Cterminal helix. Three $\mathrm{Ca}^{2+}$ ions are shown as spheres in light blue color coordinated to EF-1, $\mathrm{EF}-3$, and $\mathrm{EF}-5$. To reduce affinity for $\mathrm{Ca}^{2+}$, critical residues in position 12 for the coordination of this metal ion were mutated (E47D, E114D, and D169A). To eliminate interactions with the target protein, F122 deletion mutant was generated. These sites are shown as ball-and-stick residues in chartreuse color. The figure was generated using the Molscript program. 

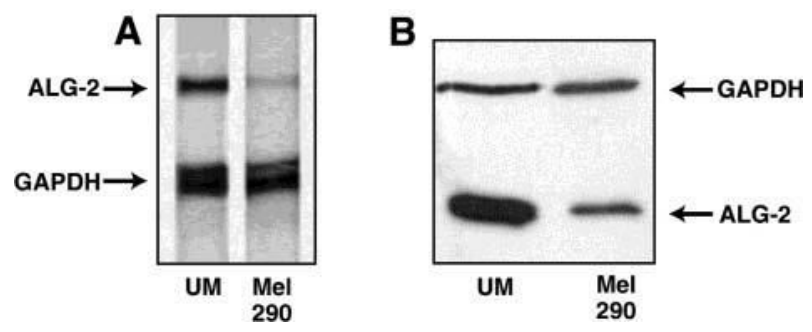

Figure 2.

Expression of ALG-2 in UM and Mel290 cells: (A) RNase protection assay comparing ALG-2 transcript levels in UM and Mel290 cells; (B) immunoblotting using UM and Mel290 whole cell lysates probed with anti-ALG-2 and anti-GAPDH antibodies. The same findings were obtained in at least three separate experiments. 

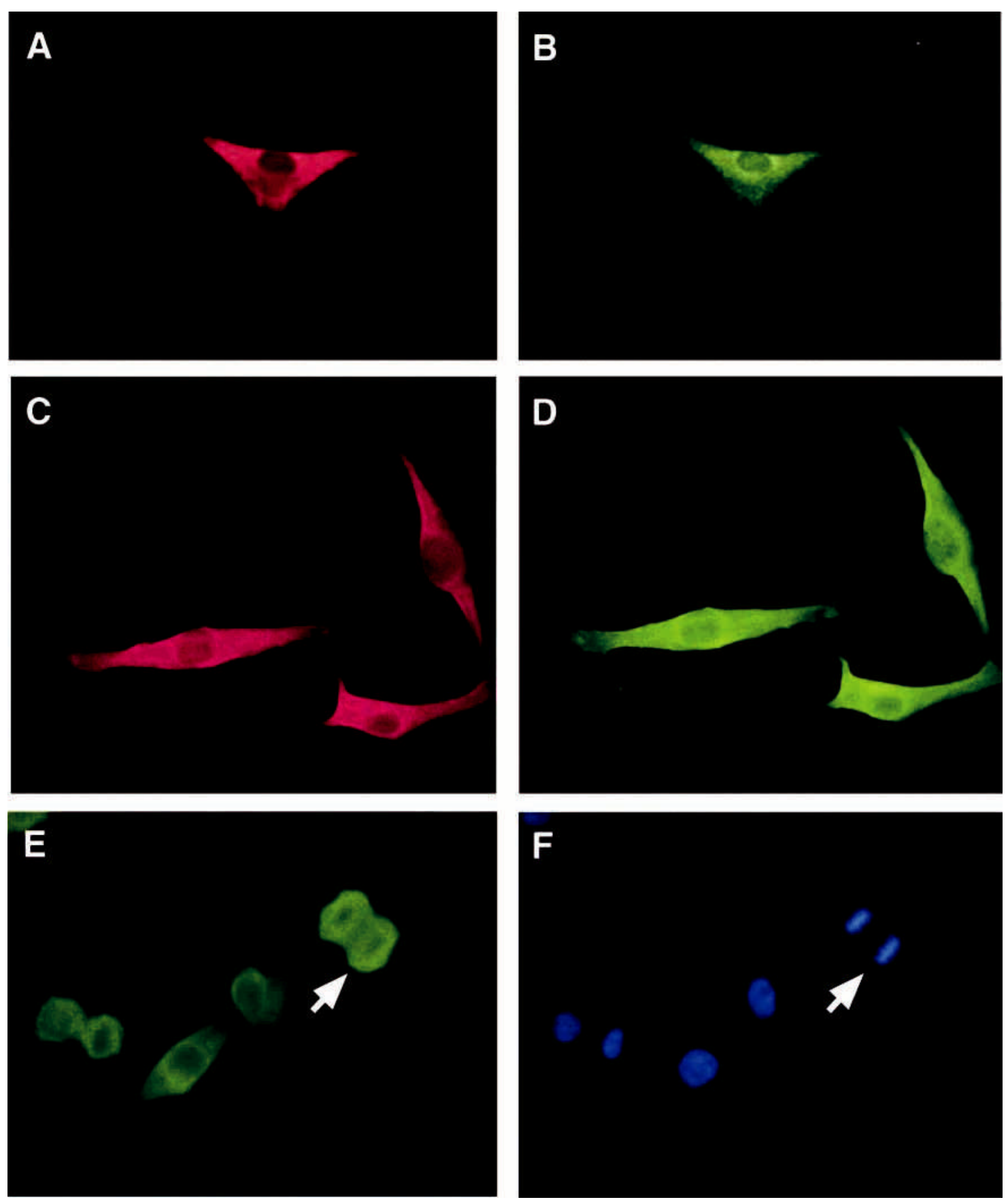

Figure 3.

Cellular localization of ALG-2 and Alix/AIP1. UM (A,B) and Mel290 cells (C,D) were immunostained with anti-ALG-2 antibodies followed by Texas red-conjugated secondary antibody (A,C) and with anti-Alix/AIP1 antibodies followed by FITC-conjugated secondary antibodies (B,D). Mel290 cells were immunostained with anti-ALG-2 antibodies (E) and Hoechst dye (F). Intense labeling of ALG-2 was observed throughout metaphase cells except in the region of condensed chromosomes, indicated by a white arrow. Results are shown from one of five similar experiments. 

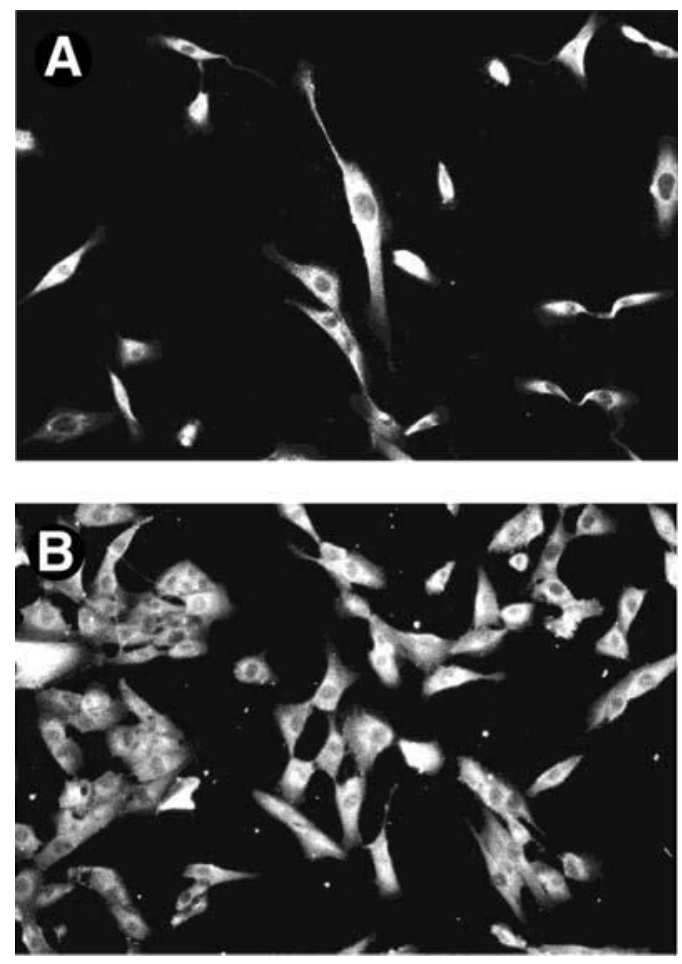

Figure 4.

Effect of $\mathrm{Ca}^{2+}$ on ALG-2 Localization. Mel290 cells were immunostained with anti-ALG-2 antibodies in the presence of EDTA (A) and $\mathrm{CaCl}_{2}(\mathrm{~B})$. Duplicate experiments were performed for each condition with the same findings. 
A
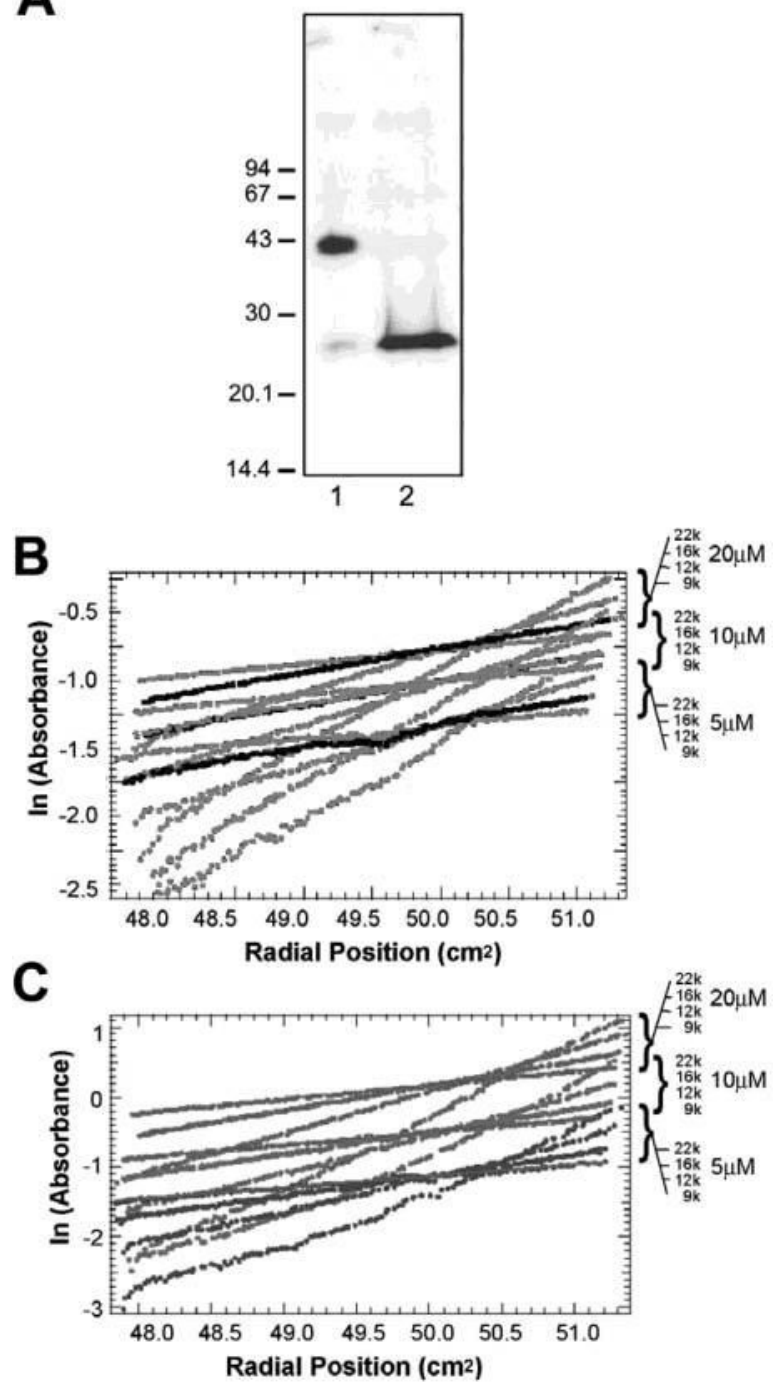

Figure 5.

Dimerization of ALG-2. In panel A, The cell-permeable cross-linker DSP was added to Mel290 cells pretreated with thapsigargin. Cells were lysed and analyzed by immunoblotting using anti-ALG-2 antibodies. Lane 1 contains cross-linked cell lysate; lane 2 contains cross-linked cell lysate solubilized in the presence of $\beta$-mercaptoethanol. In panel $B$, the absorbance at 280 $\mathrm{nm}$ was recorded for three different concentrations of ALG-2 during centrifugation in the presence of $1 \mathrm{mM}$ EDTA. The natural $\log$ of the absorbance values at equilibrium were plotted against the radial position in the three cells during centrifugation at 9000, 12000,16000 , and $22000 \mathrm{rpm}$. In panel C, a similar plot was generated from data obtained for dNALG-2 (5 $\mu \mathrm{M}$ $\mathrm{Ca}^{2+}$ ). Bold lines show the overlay of recovery values measured at $12000 \mathrm{rpm}$ after centrifugation at higher speeds with initial $12000 \mathrm{rpm}$ values, indicating little loss in protein due to irreversible precipitation. The sedimentation equilibrium curves were fitted assuming the presence of a single thermodynamically ideal species. Data were fitted as outlined in the Materials and Methods. Cross-linking data represent one of four independent experiments, while analytical centrifugation data were gathered from duplicate experiments. 

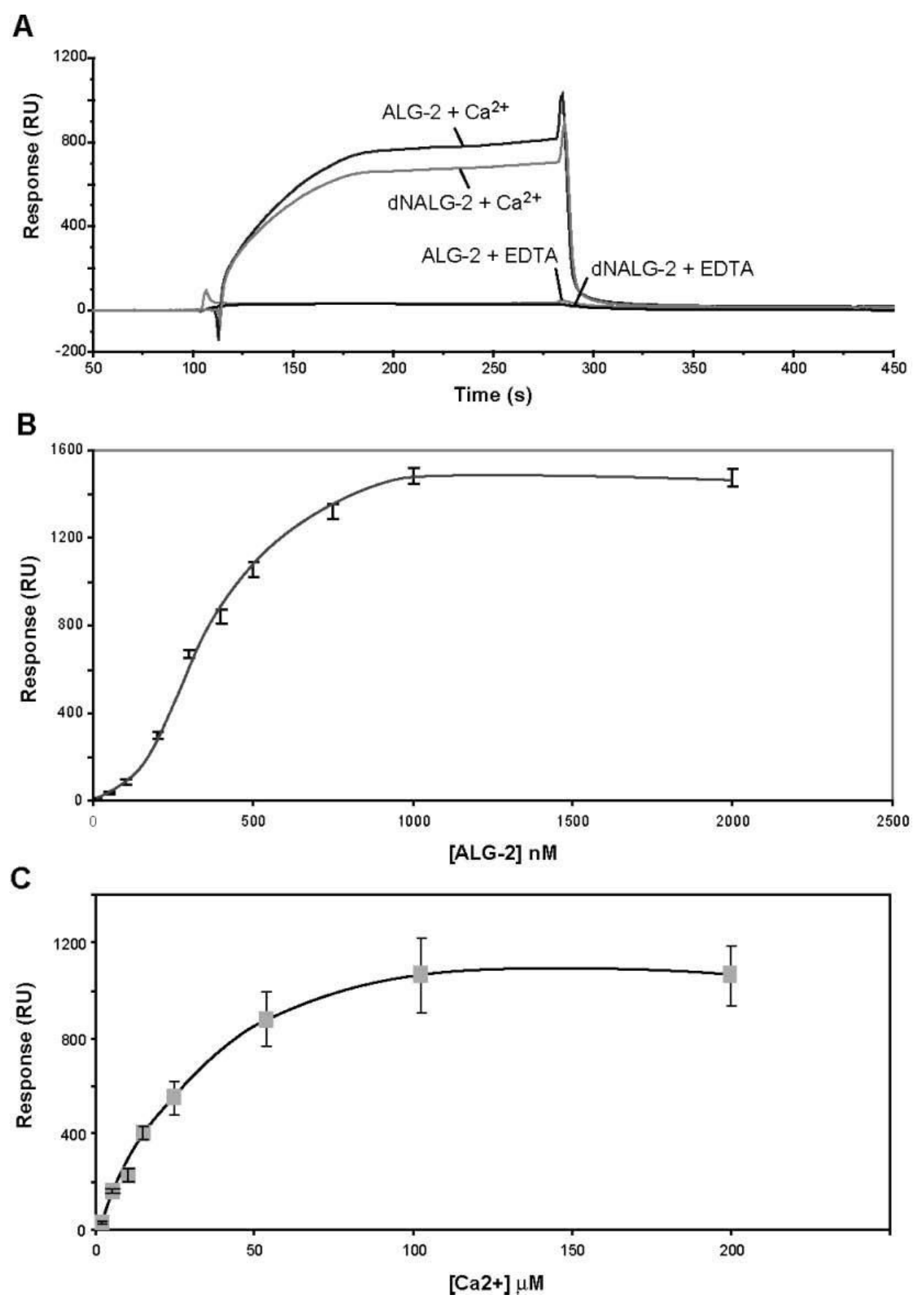

Figure 6.

Interaction of ALG-2 with Alix/AIP1. In panel A, Alix/AIP1 was immobilized to the sensor chip, and $400 \mathrm{nM}$ ALG-2 or dNALG-2 in buffer containing either $50 \mu \mathrm{M} \mathrm{CaCl}_{2}$ or $20 \mu \mathrm{M}$ EDTA was injected using the KINJECT program as outlined in the Materials and Methods. In panel $\mathrm{B}$, different concentrations of ALG-2 $(0-2 \mu \mathrm{M})$ in the presence of $50 \mu \mathrm{M} \mathrm{CaCl}_{2}$ were reacted with an Alix/AIP1 immobilized sensor chip. Average response values from duplicate runs at equilibrium plateau for each curve were plotted as a function of ALG-2 concentration. In panel $\mathrm{C}$, samples containing $400 \mathrm{nM}$ ALG-2 in the presence of varying amounts of $\mathrm{CaCl}_{2}$ $(0-200 \mu \mathrm{M})$ were injected over the Alix/AIP1 immobilized sensor chip. Average response values from duplicate runs at equilibrium plateau for each curve were plotted as a function of 
$\mathrm{Ca}^{2+}$ concentration. Response for buffer salts and $\mathrm{Ca}^{2+}$ were subtracted using an unimmobilized control flow cell in all cases. 


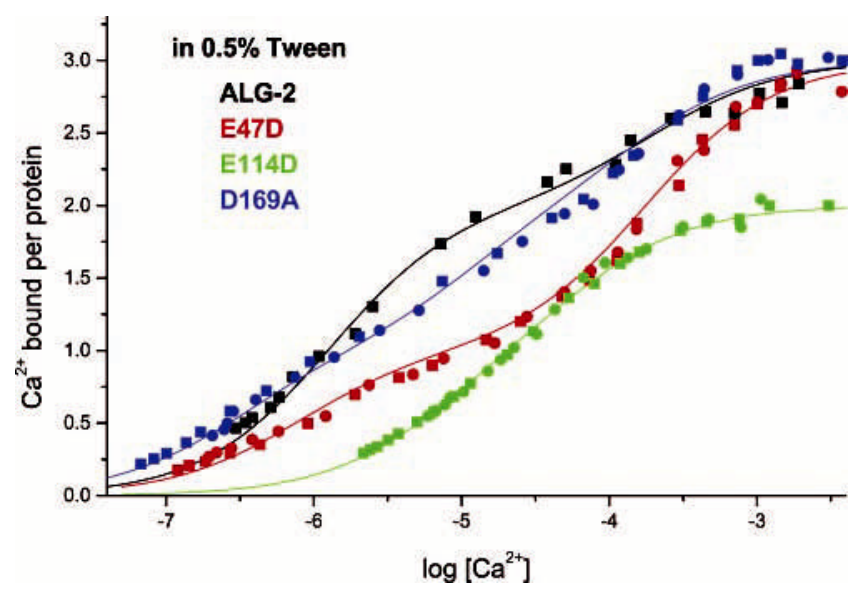

Figure 7.

$\mathrm{Ca}^{2+}$ binding by recombinant ALG-2 and three point mutants. $\mathrm{Ca}^{2+}$ binding was measured by flow dialysis at $25^{\circ} \mathrm{C}$ in $50 \mathrm{mM}$ Tris- $\mathrm{HCl}$ buffer, $\mathrm{pH} 7.5,150 \mathrm{mM} \mathrm{KCl}$ containing $0.5 \%$ Tween 20. Duplicate experiments are indicated with rectangles and circles. Intrinsic binding constants were derived from the stoichiometric constants, which were obtained by fitting of the experimental data to the Adair equation for two (E114D) or three sites (ALG-2, E47D, D169A). 
A

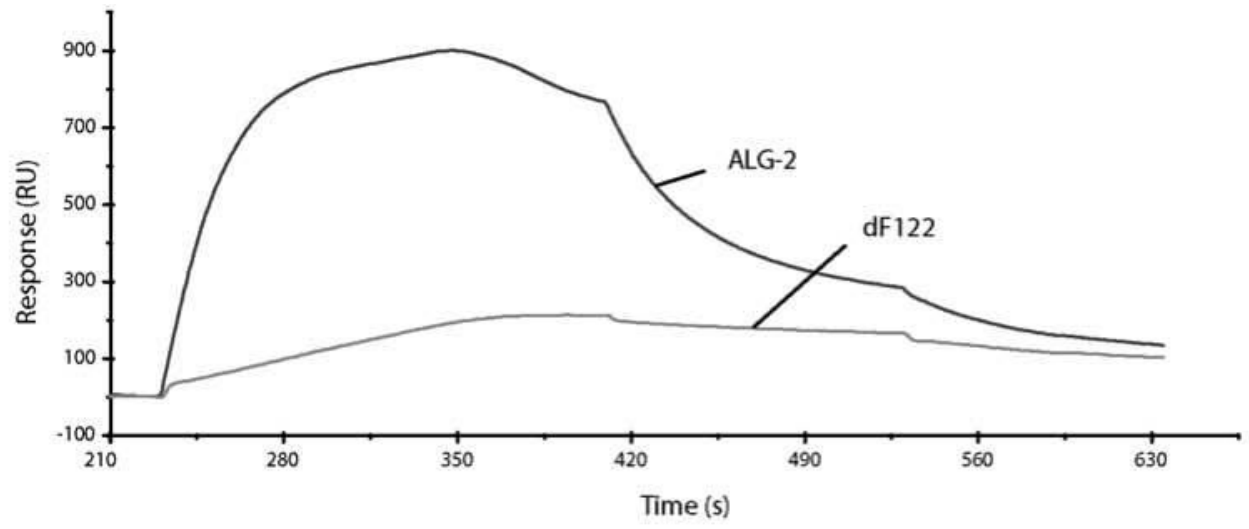

B

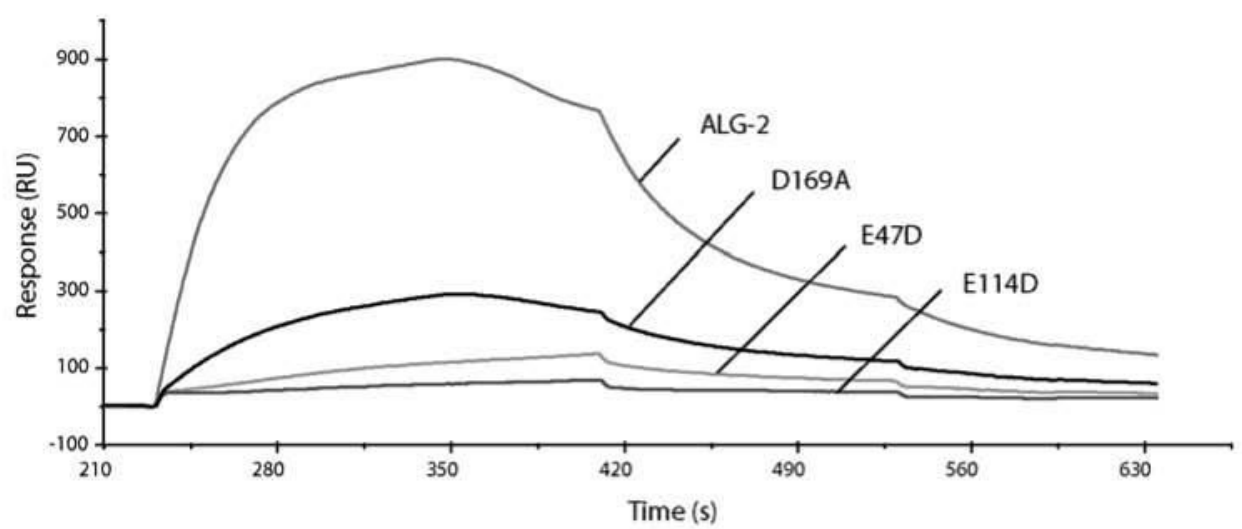

C

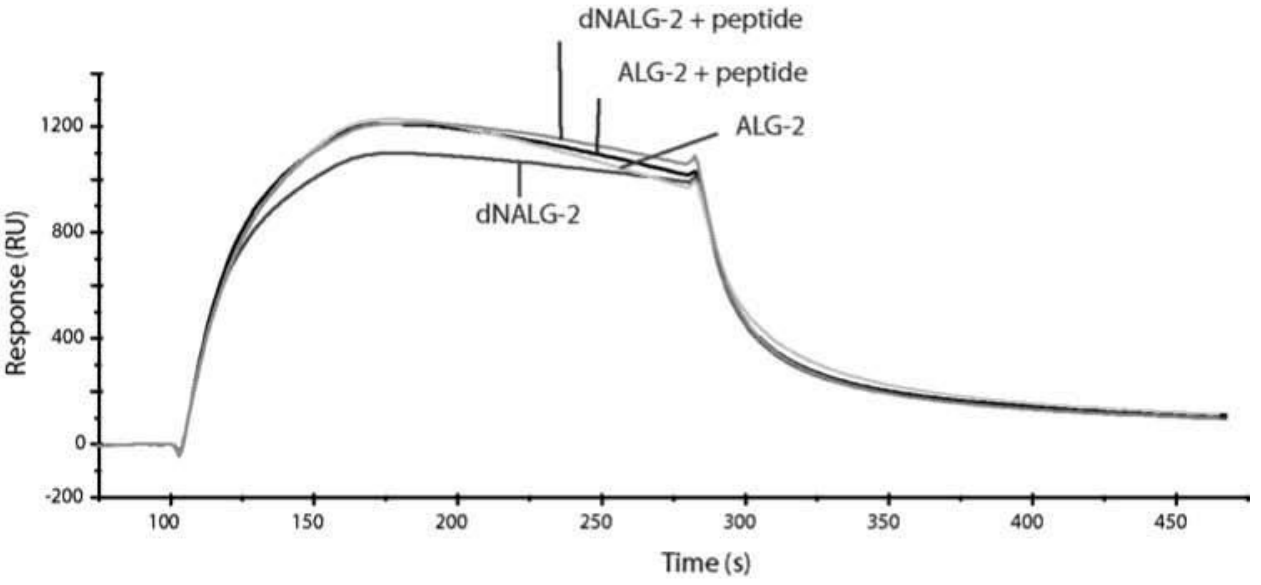

Figure 8.

Interactions of ALG-2 and mutants with Alix/AIP1. In panel A, ALG-2 and dF122 (400 nM each) were injected over the immobilized Alix/AIP1 surface in the presence of $50 \mu \mathrm{M} \mathrm{CaCl}_{2}$ using the COINJECT program outlined in the Materials and Methods. In panel B, similarly, ALG-2 and the three EF-hand mutants, E47D, E114D, and D169A were compared using the COINJECT method. In panel C, ALG-2 and dNALG-2 (500 nM each) in the presence of 50 $\mu \mathrm{M} \mathrm{CaCl}_{2}$ with or without $200 \mu \mathrm{M}$ decapeptide were analyzed by surface plasmon resonance for interaction with immobilized Alix/AIP1 using the KINJECT program. Flat plateaus as seen with KINJECT were not seen with COINJECT due to methodological differences between the two programs; however, slower dissociation rates were observable with COINJECT by 
retaining $\mathrm{Ca}^{2+}$ concentration in the dissociation phase. Experiments were conducted at least twice using duplicate samples in each experiment. 
A

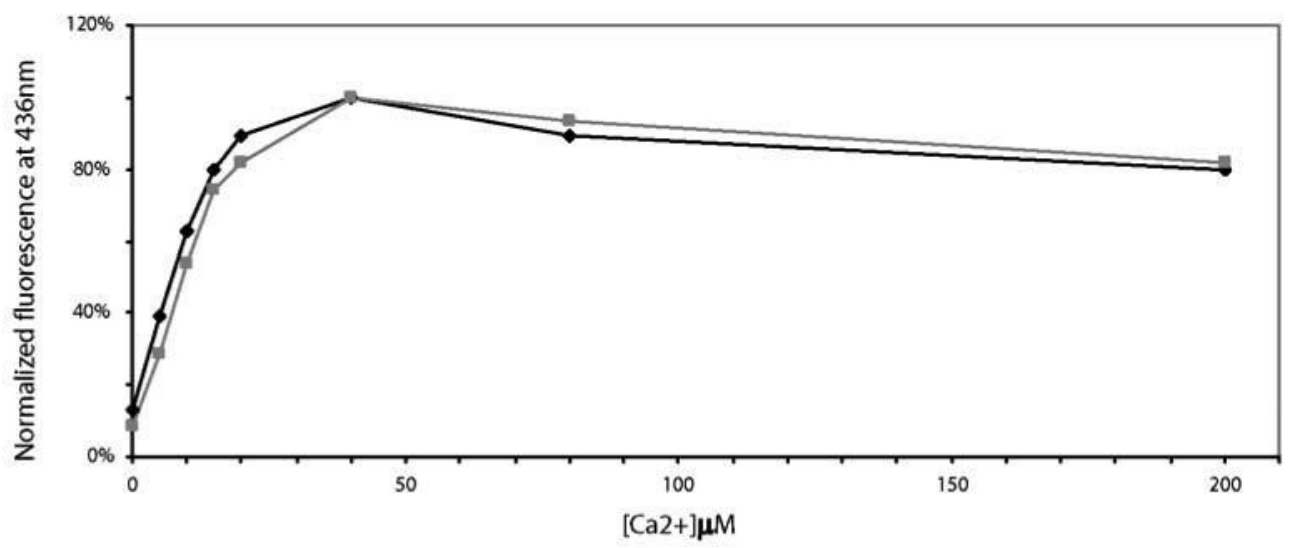

B

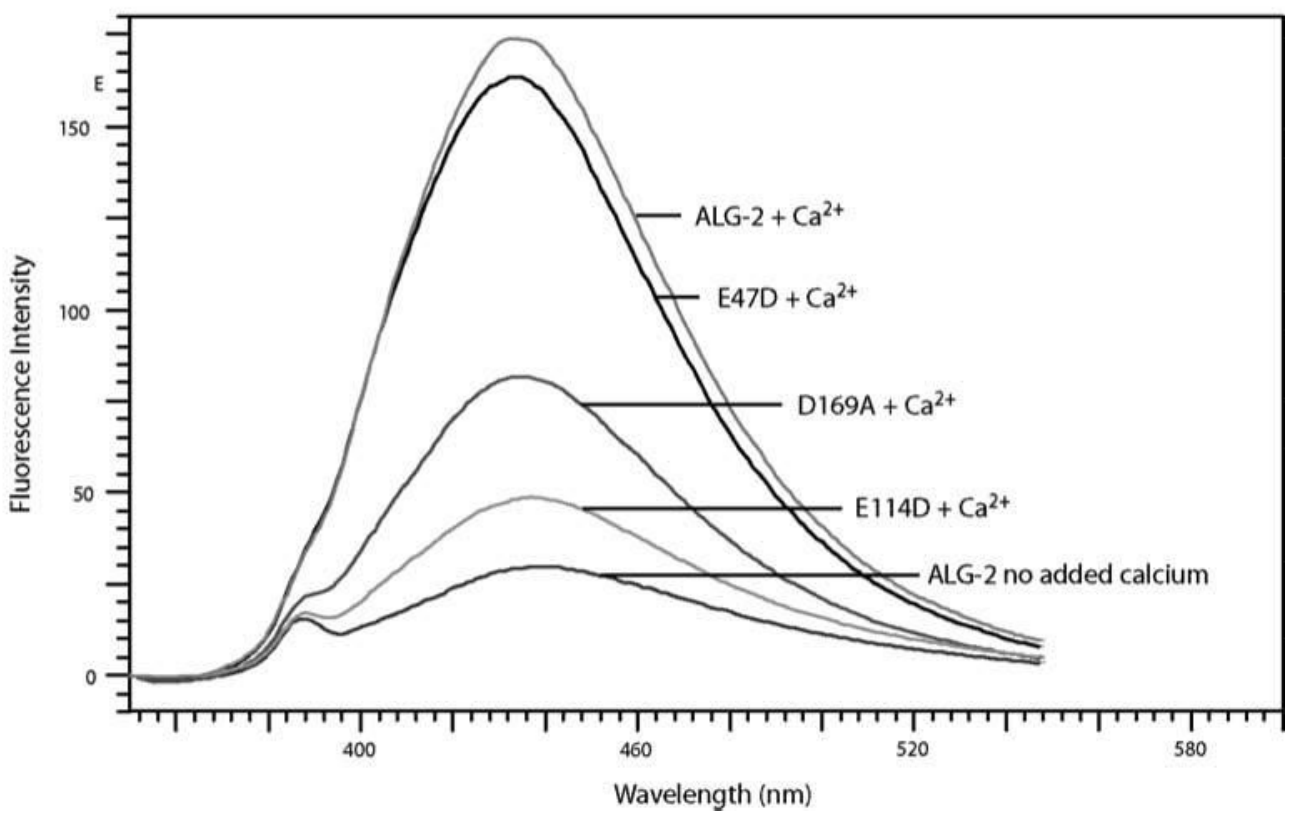

Figure 9.

$\mathrm{Ca}^{2+}$-induced conformational change in ALG-2 and mutants measured by TNS fluorescence. In panel A, fluorescence intensity values at $436 \mathrm{~nm}$ were measured for ALG-2 $(\nabla)$ and dNALG-2 (-) with varying amounts of added $\mathrm{CaCl}_{2}(0-200 \mu \mathrm{M})$. Average values from duplicate measurements were plotted as a function of $\mathrm{Ca}^{2+}$ concentration. In panel $\mathrm{B}$, emission fluorescence spectra were measured for solutions containing $2 \mu \mathrm{M} \mathrm{ALG-2,} \mathrm{E47D,} \mathrm{E114D,} \mathrm{or}$ D169A in the presence of $60 \mu \mathrm{M} \mathrm{CaCl}_{2}$ and $10 \mu \mathrm{M}$ TNS as described in the Materials and Methods. ALG-2 $(2 \mu \mathrm{M})$ with no added $\mathrm{Ca}^{2+}$ in the presence of $10 \mu \mathrm{M}$ TNS indicates basal fluorescence. 